\section{ACRL}

\section{Standards}

\title{
Standards for community, junior, and technical college learning resources programs'
}

\section{The final version, approved by ACRL, ALA, and AECT in 1994}

$\mathbf{T}$ hese revised standards apply to two-year or three-year academic institutions awarding associate degrees or certificates. They are intended to assist in evaluating and developing learning resources/library programs. With approval by the Association for Educational Communications and Technology and the Association of College and Research Libraries, the document revises and replaces "Standards for Community, Junior, and Technical College Learning Resources Programs," 1990. To remain current and useful, these standards should be reviewed and revised or rewritten on a regular five-year cycle.

Community, junior, and technical colleges make a significant contribution to post-secondary education. Academic programs parallel the first two years of education in the arts and sciences in four-year institutions. Many two-year colleges, and four-year colleges and universities have articulation agreements facilitating student transfers. Reflecting the combination of availability of courses and the expectation of successful completion of programs, more than half of the students currently pursuing higher education are enrolled in community, technical, and junior colleges. The colleges are generally community based and responsive to local needs, offering weekend and evening courses. Many colleges offer contractual courses designed to meet the special training requirements of businesses, corporations, and associations.

Moderate costs and open-access offer opportunities to students who would not otherwise be able to attend college. Emphases on vocational and adult programs and continuing education provide retraining and employment skills for many adult students. Basic education and remediation programs are common offerings.

Comprehensive standards for learning re sources programs and services are required to realize the vision of the American Association of Community Colleges of building communities $^{2}$ and to maintain excellence in teaching in two-year colleges. In most two-year institutions an expanded concept of learning resources provides diverse instructional services to the broader college community.

The term "learning resources program" is applied in these standards to an organizational configuration which provides a core of library and media materials and a variety of related services. Many programs provide unique or specialized services or have instructional responsibilities. At some colleges, library and learning resources are integrated. At others, they are parallel programs. In some, libraries are separate organizational units. The structure and function of a learning resources program within an institution are determined by the role assigned to learning resources in the institutional organization. This role must be consistent with the stated mission of the institution and its educational goals, curricula, size, and complexity; and include the diverse resources needed to accommodate different learning styles. Generally, these standards apply to a single campus location providing the basic services and activities as listed in appendix $\mathrm{A}$.

The role of the learning resources program is related to the institutional effectiveness of the college. If institutional effectiveness is measured in terms of student success in grades, credit and completion/transfer rates, learning resources standards based on circulation statis- 
tics, book counts, and other traditional measures may not be relevant because they are limited in detailing the direct impact of learning resources programs in effecting successful learning outcomes. Learning resources effectiveness measures should rely on the relational attributes of the program which directly impact learning attained by students. view is appropriate. To be meaningful and useful, the statement needs to incorporate the concerns of the college at large and the relationship of the college to the community.

1.2 The mission statement shall be used, along with institutional educational goals, in the annual planning process.

Commentary. The mission statement serves as a basis for the evaluation of services and the projection of future needs. As such, it becomes an integral part of the planning process and the starting point for institutional effectiveness review of the learning resources programs.

1.3 All component units of the learning resources program, whether adminis-

\section{Standard One: Objectives}

1.0 The college shall develop a comprehensive mission statement for the learning resources program based on the nature and purpose of the institution.

Commentary. A clear, unambiguous statement of the role of the learning resources program which relates to the effectiveness of the institution is essential for accountability, administration, and review regardless of the organizational structure of the program. For multicollege districts and multicampus community colleges separate mission statements may be needed for each college or each campus which relate to the overall statement for the districtwide learning resources program.

1.1 The mission statement shall be developed by the learning resources staff in consultation with the widest possible representation of the college community and shall be reviewed periodically.

Commentary. Assignment of responsibility to the learning resources staff for the development of the statement and for its utilization and re- tered centrally or by campus units, should be clearly defined.

Commentary. The learning resources program should include essential learning resources and media services as identified in the lists in Appendix A. Centralized and campus-based services should be clearly identified. The learning resources program may include special components beyond learning resources and media services such as those listed in Appendix B.

\section{How these standards were revised}

"Standards for Community, Junior, and Technical College Learning Resources Programs" was prepared by a joint committee of the Community College Association for Instructional Technology (CCAIT) of $\mathrm{AECT}$ and the Community and Junior College Libraries Section (CJCLS) of ACRL. Members of the commiltee are Susan M. Anderson, St. Petersburg Junior College (editor); Bernard Fradkin, College of DuPage; Khan M. Hassan (1992-93), Piedmont Virginia Community College; Wanda K. Johnston, Broome Community College; Susan M. Maltese, Oakton Community College; Lois I. Marriott, Southwestern College; Marilyn M. McDonald, Foothill College (co-chair); Gretchen H. Neill, DeKalb College (co-chair); James O. Wallace, San Antonio College (emeritus); Maj. Jerry Klopfer (1993-94), New Mexico Military Institute; and George Wilson, Tyler Junior College.

In establishing the need for joint revision, the members of the committee worked to actively encourage cooperation between ACRL and AECT. The standards were in committee for two years and represent an examination of the professional literature, testimony from a hearing held at AECT in February 1994, a hearing held at the ALA Annual Conference in June 1994, and input from a number of previous users. A draft revision was published in both Tech Trends and C\&RL News (May 1994). ACRL and ALA approved the standards in June 1994 and AECT approved them in August 1994. 
1.4 The learning resources program shall be an integral part of the institution's process for the improvement of instruction.

Commentary. An effective learning resources program is an essential component of the entire educational program. Participation by learning resources staff in curriculum development is necessary to plan effective learning resources services, to identify and acquire resources to support the curriculum, and to set priorities on the use of financial and other resources.

\section{Standard Two: Organization and Administration}

2.0 The responsibilities and functions of the component units of the learning resources program within the institutional structure shall be clearly defined.

Commentary. The administration of the institution should clearly assign responsibility for the learning resources program and identify the component units. The organizational chart should reflect the services provided and relate to the quality of the overall educational program. When restricted to only core services, the quality and impact on the instructional program may be limited; when too vaguely defined valuable resources may be too widely dispersed to be fully utilized. Clarity in identifying functions and specificity in assigning responsibilities provide a learning resources program capable of supporting the instructional needs of the students and the college community. The learning resources program should develop policies, procedures, and job descriptions and relate these to institutional policies and procedures.

2.1 The duties and responsibilities of the chief administrator of the learning resources program shall be clearly defined within the institutional structure.

Commentary. The program administrator is responsible for providing leadership and direction so that the mission of the program is fulfilled. The administrator should report to the chief academic officer and have the same administrative rank and status as other administrators with similar responsibilities. A title such as Dean or Director of Libraries, Instructional Services, or of Learning Resources is appropriate

2.2 The learning resources program administrator shall be professionally trained and knowledgeable about learning resources, information, and/or media materials and services.

Commentary. The training and experience of the program administrator shall be as a librarian, a media specialist, or an information specialist, with cross-training desirable. The minimal professional degree and prerequisite for the position is a master's degree in library or information science, educational technology or media, or learning resources services. To interact with other administrators and the learning resources staff, the administrator should demonstrate effective management skills. To make decisions on new information services, the administrator should have continuous experience with new and emerging technologies.

2.3 The comprehensive learning resources program shall include a variety of services which are organized into functional units.

Commentary. The type of component units needed and included will vary from institution to institution and campus to campus. Some possibilities are: access services, public services, telecommunication/Internet connections, technical services, media services, learning development, reprographic services, professional materials services, video production, graphics production, learning laboratories, and computer services. A listing of many of these can be found in the appendices. Services which are not administratively under the learning resources program should be in a coordinating relationship to allow comprehensive planning and reporting and to avoid duplication. For example, if a different program has responsibility for instructional computing, the learning resources program should cooperate in an advisory and consulting capacity since various computer resources are major components of the contemporary learning resource center.

2.4 The administrator and professional staff should be involved in all areas and at all levels of academic activities and institutional planning.

Commentary. Professional staff members should be involved in major college committees and participate in faculty governance to the same extent as other faculty. The program administrator should meet regularly with other college administrators and department heads and, along with professional staff members, be involved in planning, implementing, and evaluating the instructional program of the college. 
2.5 Advisory committees should be formed to provide essential information to the staff and to serve as a link with users.

Commentary. To ensure that the learning resources program is responsive to its users and to develop and evaluate effective services, advisory committees should be appointed, elected, or selected by the appropriate faculty, staff, or student constituencies.

2.6 Administration of the learning resources program should be based on staff participation and consensus.

Commentary. While the program administrator is ultimately responsible for the program, participatory governance through regular staff meetings and internal communication should be encouraged. The administrator is responsible for reporting to the staff on institutional policies, procedures, plans, budgets, personnel, and curriculum; in turn the administrator represents the learning resources staff to the college administration.

Each professional and support staff member should be provided with a position description which clearly identifies the duties and responsibilities of the position and superior and subordinate relationships. Performance appraisal standards must be clearly defined and understood by all staff members. A general learning resources manual which provides policy and procedural statements, staff respon- sibilities and duties, items of general information, and learning resources governance and operational statements shall be made available to all staff members.

\section{Standard Three: Staff}

3.0 Sufficient and qualified professional and support staff should be available to implement the services for which the program is responsible.

Commentary. Table A evaluates the requirements for adequate numbers of staff on a single campus. The figures are for full-time positions at two levels, minimum and excellent, based on full-time equivalent student enrollments. The table does not include services listed in Appendix B as peripheral. If any of these extra services are assigned, additional positions will be needed. There is a direct relationship between staff, budget, and services. When staff level and funding level increase, the number of services possible will also increase; the reverse is also true. Another factor which affects staff requirements is the ratio of total enrollment to full-time equivalent students. Headcount enrollment is often $50 \%$ greater than student full-time equivalent (FTE). The higher the ratio the greater will be the need for additional staff beyond the formulas in Table A. If there is a regular summer session at the college, the positions in Table A should be based on an eleven or twelve month equivalency. If,

\section{Table A*}

\section{Staffing Requirements for Single-Campus Services**}

\begin{tabular}{|c|c|c|c|c|c|c|c|c|}
\hline FTE Students & Administrators & Prof & sional & Tech & nicians & Othe & Staff*** & Total Staff \\
\hline & Min \& Excel & Min & Excel & Min & Excel & Min & Excel & Min Excel \\
\hline under 1,000 & 1 & 2 & 4 & 2 & 4 & 2 & 3 & $\begin{array}{ll}7 & 12\end{array}$ \\
\hline $1,000-2,999$ & 1 & 3 & 5 & 3 & 6 & 3 & 6 & 10 \\
\hline $3,000-4,999$ & 1 & 5 & 7 & 5 & 8 & 4 & 8 & $15 \quad 24$ \\
\hline $5,000-6,999$ & 1 & 7 & 9 & 7 & 12 & 6 & 11 & $21 \quad 33$ \\
\hline $7,000-8,999$ & 1 & 8 & 11 & 9 & 17 & 7 & 14 & 43 \\
\hline $9,000-10,999$ & 1 & 10 & 15 & 11 & 20 & 9 & 17 & 53 \\
\hline $11,000-12,999$ & 2 & 14 & 21 & 13 & 24 & 11 & 20 & $40 \quad 67$ \\
\hline $13,000-14,999$ & 2 & 16 & 24 & 16 & 28 & 13 & 24 & $47 \quad 78$ \\
\hline $15,000-16,999$ & 2 & 18 & 27 & 19 & 32 & 16 & 28 & $55 \quad 89$ \\
\hline $17,000-19,000$ & 2 & 20 & 30 & 21 & 36 & 18 & 32 & 61100 \\
\hline
\end{tabular}

*Does not include student assistants

${ }^{* *}$ Additional staff will be needed if enrollment is $50 \%$ greater than FTE

***Secretaries, clerks, lab aides, etc. 
in a multicampus or multicollege district, some services are centralized, for example, technical services and automation, personnel will be needed at a centralized site in addition to those needed in the campus libraries.

3.1 The professional staff members shall have a graduate degree from an accredited institution and shall have faculty status, benefits, and obligations or the equivalent.

Commentary. The complexity of the learning resources program may require considerable differentiated staffing by individuals with widely varied professional education and areas of specialization. All should have the same status, benefits, and recognition as other facuity and where faculty rank exists they should meet the same requirements for promotion and tenure as other faculty.

3.2 Professional staff should belong to and participate in library, learning resources, media, and other appropriate associations. Professional development should be encouraged through direct financial support of attendance and participation in local, state, and national organizations.

Commentary. The mark of a professional is not only performance on the job but also knowledge of trends within the profession and technological developments learned from conferences, workshops, and journals; and by assuming leadership within the field.

3.3 The changing nature of learning resources programs and ongoing changes in technology mandate regular staff participation in continuing education.

Commentary. Duty schedules should be flexible enough for staff to pursue job-related training and education, in-service workshops, and conferences and meetings during working hours. The institutional budget should include

\section{Table B*}

Learning Resources Budget As \% of Educational \& General Expenditures

\begin{tabular}{lll}
\hline Size & Minimum & Excellent \\
\hline All & $6 \%$ & $9 \%$ \\
\hline
\end{tabular}

*Appendix B activities and services will require additional funding provision for travel and fees, and release time for in-service training, and education.

3.4 Technical and classified personnel should have appropriate specialized training or experience. Classification, status, and salary should be equivalent to those provided for other institutional employees with similar qualifications.

Commentary. Requirements for training and experience needed should relate to the duties assigned. The relative importance of each type of skill will vary across organizational levels. Supervisors should be selected on the basis of knowledge, experience, and human relations skills.

3.5 Student assistants perform a variety of tasks that assist and complement professional staff, clerical staff, and technicians. Student assistant programs offer work opportunities and career exploration for student workers.

Commentary. The tasks performed by student assistants are usually routine, although some students bring advanced or technical skills which supplement the skills of the regular staff. Permanent staff should supervise and instruct student workers.

\section{Standard Four: Budget}

4.0 The mission statement should form the basis for the program budget and be part of the institutional planning process; annual objectives should be developed by the learning resources staff.

Commentary. The mission statement and annual objectives form the basis for the program budget. Stable and consistent funding for acquisitions based on an approved collection development policy is necessary for effective service. Inconsistent funding is the most detrimental element in the development of learning resources collections.

4.1 An ample and stable budget should be based either on a percentage of educational and general budget totals for the institution as shown in Table B or based on a dollar amount per full-time student equivalent as shown in Table C.

Commentary. Basing the learning resources budget totals on a percentage of the college educational or general fund is the preferred approach, but many variables make it difficult to determine the dollar amount of a 
percentage during the budget planning process. Capital funds are not included in the percentage except for acquisition of learning resources materials.

A formula using a dollar figure per full-time student equivalent provides a more stable basis for planning collections and services than using a percentage. Table $C$ is based on 1992 dollars; inflation requires these figures to be adjusted upward accordingly. There is a correlation between services, collection, and staff size and the level of expenditures.

4.2 Local processes should be developed so that all expenditures originate within the learning resources program and are reviewed by the chief administrator.

Commentary. Management involves responsibility for expenditures and approval of payments. Budgeting cost analyses and financial planning depend on adequate records. To take advantage of discounts, purchases of materials should be exempt from restrictive bidding and should permit online ordering and standing orders.

4.3 Internal accounts should be maintained for evaluating the flow of expenditures, monitoring encumbrances, and approving payment of invoices.

Commentary. An accurate account of expenditures in categories that are meaningful to the institution is necessary for fiscal accountability, for monitoring status of accounts, for decision making, and for planning.

4.4 The learning resources budget should provide stable funding for contractual services, equipment and materials replacement, and for maintenance of automated public and technical services.

Commentary. Many services are based on continuing support. They cannot be interrupted without serious constraint on the ability to perform effectively. The materials in the collection will become stagnant without a three to five percent replacement of older materials each year.

\section{Table $\mathrm{C}^{3}$}

\section{for Learning Resources by Category}

\begin{tabular}{lc|r} 
Category & Minimum 50\%ile & Excellent 90\%ile \\
\hline Salaries \& Wages & $\$$ & \multicolumn{1}{c}{$\$$} \\
Print Materials & 92.97 & 177.74 \\
Current Serials & 8.69 & 37.47 \\
Microforms & 2.11 & 22.20 \\
Machine Readable & 1.25 & 6.91 \\
Audiovisual Material & 3.12 & 6.24 \\
Other Material & 1.43 & 10.04 \\
Preservation & 0.34 & 6.33 \\
Equipment & 5.41 & 2.07 \\
Contract Computer & 3.21 & 24.00 \\
Telecommunications & 0.67 & 11.08 \\
Computer Hardware & 4.27 & 3.39 \\
All Other Expenditure & 10.30 & 15.30 \\
Postage & 0.29 & 38.99 \\
\end{tabular}

4.5 All directly related revenues such as fines, payments for lost and damaged materials, sale of unneeded items, and student use fees, should be used solely for the support of collections, services, and activities of learning resources programs.

\section{Standard Five: User Services}

5.0 The learning resources program should provide a variety of services that support and expand the instructional capabilities of the institution.

Commentary. Learning resources programs exist to facilitate and improve education by supporting and expanding classroom instruction and to provide the instructional function of teaching students information-seeking skills for self-directed studies and lifelong learning. As an integral part of the total educational program of the institution, the learning resources program provides instructional as well as support services to students, faculty, and staff which can be demonstrated by the ratio of users to enroliment.

The primary purpose of the learning resources program is to promote learning related to the curriculum of the institution. To do this the learning resources program should provide the best possible access to information in print, media, or electronic format, and have the means for delivering the information to individual us- 
ers, groups, and classrooms. Access should be from the institution's own collection of materials paired with efficient supportive equipment and services. To integrate new information and new instructional technologies into the curriculum, access and delivery systems should be extended through such means as cooperative borrowing (ILL), resource sharing, renting or leasing services and materials, and the use of electronic databases and other technologies as listed in the appendices.

Students should have access to materials and professional assistance at all times the facility is open. Faculty members should have access to basic instructional media production assistance and assistance in research projects.

5.1 The learning resources program should seek to enlarge access to the academic services available at the college and in the community in accordance with the college mission through networking, resource sharing, online information services, and technological advances.
Commentary. Institutional self-sufficiency is no longer desirable or feasible; and provision must be made to utilize new delivery systems. New technologies and new services should be adopted as they become useful to meet institutional goals. The administrator should be prepared to bring to the attention of the faculty and administration new information formats and services as they emerge.

5.2 Services provided should meet the instructional and informational needs of students, faculty, staff, and administration; should provide professional assistance; and should include a minimum of information access provision for students in off-campus locations

Commentary. Professional staff must be accessible to students to help them gain the skills needed to become self-reliant and critical users of information services. Close cooperation with classroom instructional faculty is mandatory. Off-campus services must be supported by the institution or by contracted services through another library in accordance with ACRL's "Guidelines for Extended Campus Library Services."

\section{Table D}

Longevity and/or Obsolescence of Information Access Equipment

\begin{tabular}{lc} 
Equipment Type & Years \\
\hline I6mm projector & 10 \\
Slide projector & 11 \\
Sound slide projector & 8 \\
Sound filmstrip projector & 9 \\
Overhead projector & 11 \\
Opaque projector & 14 \\
Audiocassette recorder & 9 \\
Record player & 9 \\
Portable PA system & 7 \\
Videocassette recorder & 7 \\
Television monitor/receiver & 9 \\
Video camera/camcorder & 5 \\
Microcomputer system & 5 \\
LCD panel & 4 \\
Video projector & 5 \\
CD-ROM player & 5 \\
Microform reader/printer & 6 \\
Telefacsimile equipment & 3
\end{tabular}

Rapid changes in technology affect equipment life spans as obsolescence becomes as great a factor as longevity.

Source: Wanda K. Johnston, Administering the Community College Learning Resources Program (Boston: G.K. Hall Ref., 1994), p. 93. Reprinted with permission.
5.3 Necessary equipment to access information and to assist instruction should be available and efficiently managed.

Commentary. Equipment must be available when and where it is needed. Equipment may be kept permanently in appropriate classrooms or where materials are found. Equipment must be maintained in good operating condition and should be replaced on a scheduled basis, taking into consideration obsolescence and operating condition (see Table D). Capital funds must be available to insure that advantage can be taken of technological advances. The test for this standard is that less than $10 \%$ of the available instructional equipment is inoperable at any time.

5.4 Provision should be made for instructional support production services.

Commentary. Minimum production services should consist of 
visualization services, such as overhead transparencies and projected visuals; and audio services, such as recording of lectures and speeches; and duplication of these. As staff and budget allow additional production capabilities should be added to meet instructional requirements.

5.5 An information literacy program for students should be provided through a variety of techniques.

Commentary. A major responsibility of the learning resources program is to provide instruction in locating, accessing, and evaluating information resources in a variety of formats or locations. In acldition to general orientation programs, bibliographic instruction may use many different methods, including group and individual instruction and credit or noncredit courses. Basic reference service should provide individualized assistance at all hours the facility is open. The goal is to prepare students for lifetime use of information resources.

\section{Standard Six: Collections}

6.0 The learning resources program shall make available an organized collection of materials and information in diversified formats including print and nonprint media, computer software, optical storage technologies, and other.

Commentary. The institution should be prepared to utilize new technologies for accessing information as they are developed. All types of materials conveying intellectual content, artistic and literary works, programmed texts, and packaged instruction are considered resources for effective teaching and learning along with books, periodicals, newspapers, government documents, and microforms. Media materials, including those locally produced, play a vital role in the instructional program of most two-year colleges. The increasing volume of specialized, high-quality information recorded on videotape at relatively low cost gives the videocassette format a key role in delivering current information across all disciplines. Computer software must be treated as a curricular resource. Online computer services and Internet access are increasingly important as information resources along with CD-ROM and video disc technologies.

Table $\mathbf{E}$ provides collection goals using definitions from the Integrated Postsecondary Edu- cation Data System (IPEDS) of the U.S. Department of Education. Quantities under the various columns can be interchanged according to the mission of the institution. For example, an institution with a very strong music program may need to develop a collection of sound recordings or video recordings in excess of these quantitative standards but may need less of some other items. The basis for evaluation in such a case would be the total holdings for that size institution.

6.1 A collection development policy statement shall serve as the basis for selection and acquisition of materials.

Commentary. Acquiring materials based on a written policy with clear guidelines for selection is the nature of collection development. The statement should be developed in consultation with instructional faculty, students, and administrators. Although there are many alternative ways of writing a collection development policy, the following essentials should be included:

a. The purpose for which resources are required.

b. The primary clientele who are to be served.

c. The kinds of materials which are to be acquired.

d. The various factors of cost and suitability which will be considered in determining acquisition priorities.

e. The procedures for handing new types of materials, such as computer software and videocassettes, in conformance to copyright law.

f. The process for leasing or renting materials not readily available or too expensive to purchase.

g. Any arrangements with other institutions for resource sharing, cooperative collections, production, or distribution activities.

h. A statement in support of intellectual freedom and the "Library Bill of Rights."

i. A policy on the acceptance and incorporation of gifts into the holdings which recognizes inherent processing and storage costs.

j. A policy for the de-selection or withdrawal of materials and a method to discard or dispose of them.

6.2 The selection of materials should be coordinated by the professional staff, working closely with the campus community. Final management decisions as to the order in which 
materials are to be purchased and what gifts should be accepted and processed are the responsibility of the program administrator.

Commentary. Professionally trained librarians and information specialists, because of their knowledge of the collection, are best able to give systematic attention to collection development. Knowledge of existing holdings, identified weaknesses, and acquisitions decisions requires the systematic attention of professional librarians. They should have access to bibliographical tools and reviewing sources for effective collection development.

6.3 The collection shall be of sufficient scope and currency to support the curriculum as well as meet individual information needs of students and faculty.
Commentary. The mission of the college will determine the complexity of the collection, but an institutional commitment to excellence means building and maintaining collections that adequately support: liberal arts and sciences programs to prepare students fully for transfer to four-year colleges and universities; programs that have specialized accreditation (fields such as allied health); vocational and technical programs; special programs for job training, retraining, or upgrading of skills through continuing and community education services; and needed remedial programs for nontraditional or underprepared learners. A broad spectrum of materials must be available to meet research assignments, classroom reports, and self-paced learning.

Table E

Size of Collection for a Single Campus

Minimum Collection

\begin{tabular}{rrcrrr}
\hline FTE Students & Volumes & $\begin{array}{c}\text { Current } \\
\text { Serials Subs. }\end{array}$ & $\begin{array}{l}\text { Video } \\
\text { \& Film }\end{array}$ & $\begin{array}{r}\text { Other } \\
\text { Items* }\end{array}$ & $\begin{array}{c}\text { Total } \\
\text { Collection }\end{array}$ \\
\hline under 1,000 & 30,000 & 230 & 140 & 2,500 & 32,870 \\
$1,000-2,999$ & 40,000 & 300 & 400 & 5,100 & 45,800 \\
$3,000-4,999$ & 60,000 & 500 & 750 & 8,000 & 69,250 \\
$5,000-6,999$ & 80,000 & 700 & 1,250 & 10,000 & 91,950 \\
$7,000-8,999$ & 95,000 & 850 & 1,600 & 12,000 & 109,450 \\
$9,000-10,999$ & 110,000 & 900 & 1,800 & 14,800 & 127,500 \\
$11,000-12,999$ & 125,000 & 1,000 & 2,000 & 17,400 & 145,400 \\
$13,000-14,999$ & 140,000 & 1,200 & 2,200 & 19,800 & 163,200 \\
$15,000-16,999$ & 155,000 & 1,500 & 2,400 & 22,000 & 180,900 \\
$17,000-19,000$ & 170,000 & 1,800 & 2,600 & 24,000 & 198,400 \\
\hline
\end{tabular}

\section{Excellent Collection}

\begin{tabular}{rrcrrr}
\hline FTE Students & Volumes & $\begin{array}{c}\text { Current } \\
\text { Serials Subs. }\end{array}$ & $\begin{array}{l}\text { Video } \\
\text { \& Film }\end{array}$ & $\begin{array}{r}\text { Other } \\
\text { Items* }\end{array}$ & $\begin{array}{c}\text { Total } \\
\text { Collection }\end{array}$ \\
\hline under 1,000 & 45,000 & 400 & 560 & 5,000 & 50,960 \\
$1,000-2,999$ & 60,000 & 600 & 800 & 8,000 & 69,400 \\
$3,000-4,999$ & 85,000 & 800 & 1,300 & 11,600 & 98,700 \\
$5,000-6,999$ & 112,000 & 1,000 & 2,250 & 18,000 & 133,250 \\
$7,000-8,999$ & 136,000 & 1,200 & 3,000 & 21,000 & 161,200 \\
$9,000-10,999$ & 166,000 & 1,400 & 3,300 & 26,000 & 196,700 \\
$11,000-12,999$ & 200,000 & 1,600 & 4,000 & 31,000 & 236,600 \\
$13,000-14,999$ & 240,000 & 1,800 & 4,500 & 35,000 & 281,300 \\
$15,000-16,999$ & 285,000 & 2,100 & 5,000 & 41,000 & 333,100 \\
$17,000-19,000$ & 320,000 & 2,400 & 5,600 & 50,000 & 378,000
\end{tabular}

*Includes microforms, cartographic, graphic, audio, and machine-readable materials. 
6.4 Obsolete, worn-out, and inappropriate materials should be removed based on a policy statement.

Commentary. De-selection or withdrawal on a regular basis is indispensable to a useful collection and should be done systematically. A written policy should govern what should be removed, what should be replaced, and what should be permanently retained. Not only do obsolete and inappropriate materials occupy expensive storage space but they also detract from other materials containing important information. From three to five percent of the collection should be replaced annually. The physical condition of the collection should be reviewed regularly and needed repairs to materials should be made.

6.5 The reference collection shall include a wide selection of standard works, with subject bibliographies and periodical indexes in print and electronic formats.

Commentary. Reference is the core of every library or learning resources program and the beginning point for research. The reference collection should be of sufficient breadth and depth to serve the research and informational needs of the campus community.

6.6 Collections should be organized to provide users with full, efficient, and direct access.

Commentary. The choice of a classification system, the type of catalog, and the arrangement of materials are important decisions. Nationally approved systems (such as the Library of Congress [LC] or Dewey classification schemes) and formats (such as Machine Readable Cataloging [MARC]) are standard. Uniform and multiple access through a public access catalog is essential to make available information in all types of formats. The public access catalog should include bibliographic records and information for all formats included in the collection.

\section{Standard Seven: Facilities}

7.0 The learning resources program should provide adequate space for housing collections in a variety of formats, for study and research, for public service activities, for staff workrooms and offices, and for basic production.

The total number of assignable square feet recommended for a building that houses these functions can be calculated by applying a formula that reflects:

- number of FTE students enrolled;

- public services provided;

- size and type of collections;

- number of staff members and their needs.

Since some public higher education regulatory agencies issue space formulas for campus facilities, building planners should investigate guidelines that exist in their state early in the planning process. An example of a state-mandated formula is found in Appendix $\mathrm{C}$.

Commentary. Local conditions and unique needs of colleges will determine the ultimate size of the building. Flexibility is desirable in assigning learning resources space. Most services should be housed in a central location on a campus. When components are located elsewhere, this should be based on the most efficient and effective access to services. Facilities must be planned for long-term service, including anticipated growth and changing formats of collections, projected increase of the student population, sufficient space for work areas, equipment, storage, and the needs of users. Space planning must take into account the changing information environment, the need for computer workstations, for transmission and retrieval of information by telecommunication, for media production, and for physical requirements within the building for electrical and telecommunications connections and for services for the physically disabled. Additional space should be provided when special services are included in the learning resources program.

7.1 Student seating should approximate a minimum of $10 \%$ of the FTE enrollment. The space for user activities should accommodate a wide variety of learning styles and study situations, should be attractive, comfortable, and designed to encourage use. Different types of seating arrangements should be offered, including:

- individual carrels, 25 sq ft per student;

- tables for four, $25 \mathrm{sq} \mathrm{ft}$ per student;

- lounge chairs, $30 \mathrm{sq}$ ft per student;

- computers and workstations, $40 \mathrm{sq} \mathrm{ft}$ per student;

- microform reader stations, 35 sq ft per student;

- small group study rooms, 25 sq ft per student. 
In addition to seating, public services areas should include space for public access catalogs, current periodicals, indexes, reference and technology delivery areas, display and exhibit space, group bibliographic instruction, group viewing, and study areas for faculty.

Commentary. Proper arrangement and sufficient space for utilization of instructional equipment and materials, for the needs of the physically disabled, and for both quiet individual study and conference and group study is essential. Advances in technology require flexibility and planning for use of specialized equipment, electrical and computer connections, cables, conduits, lighting, environmental control, fire protection, security, and other factors that affect service. The use of telecommunications necessitates computer connections to faculty offices, classrooms, and outside locations.

7.2 The generally accepted formula for books and other bound collections is calculated at 10 bound volumes per assignable square foot. This number should be cloubled to 20 volumes per square foot if compact shelving is used. Other materials such as audiovisual, software, microforms, maps, archives, etc. should be converted to volume equivalents by using one of the existing conversion tables available in the literature and should be included in the total stack estimate. Anticipated growth of the collection should be factored into the calculation.

Commentary. By eliminating unnecessary aisles between each range, compact shelving saves space by doubling shelving capacity and should be considered as a method to maximize storage of print materials in areas of the collection not heavily used. Because the system is very heavy, compact shelving will not be suitable unless the floor loading permits.

7.3 Staff space for workrooms, offices, equipment areas, etc. should be in compliance with state and institutional guidelines (7.0). A minimum of 175 square feet per staff member to accommodate new technologies, equipment, and hardware is desirable. Individual offices for professional staff and administrators should be figured at 200 square feet per person (Boss, p. 108).

7.4 New construction and remodeling projects must be in compliance with the Amer- icans with Disabilities Act (ADA) enacted July 1990.

7.5 Space assigned to learning resources should be restricted to the functions for which it was designed.

Commentary. Space designed for learning resources use should not be used for other institutional activities.

\section{Notes}

1. The term "learning resources program" refers to an umbrella organization which encompasses a variety of services. Other frequently used titles for this program include: library services, educational support services, and instructional services.

2. See American Association of Community and Junior Colleges, Building Communities: $A$ Vision for the New Century, A Report of the Com mission on the Future of Community Colleges, 1988 .

3. Statistical Norms for College and University Libraries: Derived from U. S. Department of Education Fall 1992 Survey of College and University Libraries (Boulder, Colo.: John Minter Assoc., 1993).

\section{References}

"ACRL guidelines for extended campus library services." CERL News 51 (April 1990): 353.

American Association of Community and Junior Colleges. Building Communities: A Vision for the New Century, A Report of the Commission on the Future of Community Colleges. 1988.

Boss, Richard. Information Technologies and Space Planning for Libraries and Information Centers. Boston: G.K. Hall Ref., 1987.

Johnston, Wanda K. Administering the Community College Learning Resources Program. Boston: G.K Hall Ref., 1994.

Martin, Ron G. Libraries for the Future: Planning Buildings That Work. Papers from the LAMA Buildings Pre-Conference, June 27-28, 1991. Chicago: ALA, 1992.

Merril, Irving, and Harold Drob. Criteria for Planning the College and University Learning Resources Center. Washington, D.C.: AECT, 1977.

Metcalf, Keyes, et al. Planning Academic and Research Library Buildings, second edition. Chicago: ALA, 1986. 


\section{APPENDIX A: CHECKLIST OF BASIC LRC SERVICES AND ACTIVITIES}

Listed below are specific services which are considered to be normal and basic library services in two-year college learning resources or emerging program budgets. This list may not include future or emerging technologies and services. Inclusion does not mean that an institution should have every activity or service listed.

Acquisitions, cataloging, maintenance, preservation, and/or circulation of:

- Audiovisual materials/programs

- Books

- College archives including institutional publications

- Computer programs

- Government documents

- Laser optical (CD-ROM) resources

- Local history materials

- Microforms

- Periodicals

- Special collections

\section{Computer systems management and maintenance:}

- Computer programs

- Gateway and Internet access

- Integrated automation systems

- Local area networks (LANs) and wide area networks (WANs)

- Public access computers

\section{Equipment services:}

- Equipment inventory, scheduling, and distribution

- Equipment maintenance and repair

- Equipment specifications and purchase

- Group viewing services

- Public access listening/viewing area

\section{Instructional services:}

- Bibliographic instruction

- Bibliographies

- Computer literacy

- Copyright consultation

- Group orientation
- Individualized instruction and/or self-paced learning assistance

- Instructional design and development

- Media orientation and instruction

- Online databases searching

- Point-of-use guides, pathfinders, and study guides

- Reference service

- Reserve materials

- Staff development

- Telephone reference

\section{Production services:}

- Audio duplication, editing, and recording

- Copy machines, paper and microform

- Drymounting and lamination

- Graphic layout and design

- Interactive video

- Multimedia

- Photography and darkroom

- Satellite communications downlink

- Scripting

- Teleconference services

- Telecourse and distant learning distribution

- Transparencies and slides

- Video duplication, recording, and editing

\section{Resource sharing services:}

- Bibliographic networks

- Gateway services

- Interlibrary loan (ILL)

- Internet

- Reciprocal borrowing

- Rental and free-loan materials

- Union catalogs of local resources
"Standards for community, junior, and technical college learning resources programs." College \& Research Libraries News 51 (September 1990): 757 .
Statistical Norms for College \& University Libraries: Derived from U.S. Department of Education IPEDS 1992 Survey of Academic Libraries. Boulder, Colo.: John Minter Assoc., 1993. 


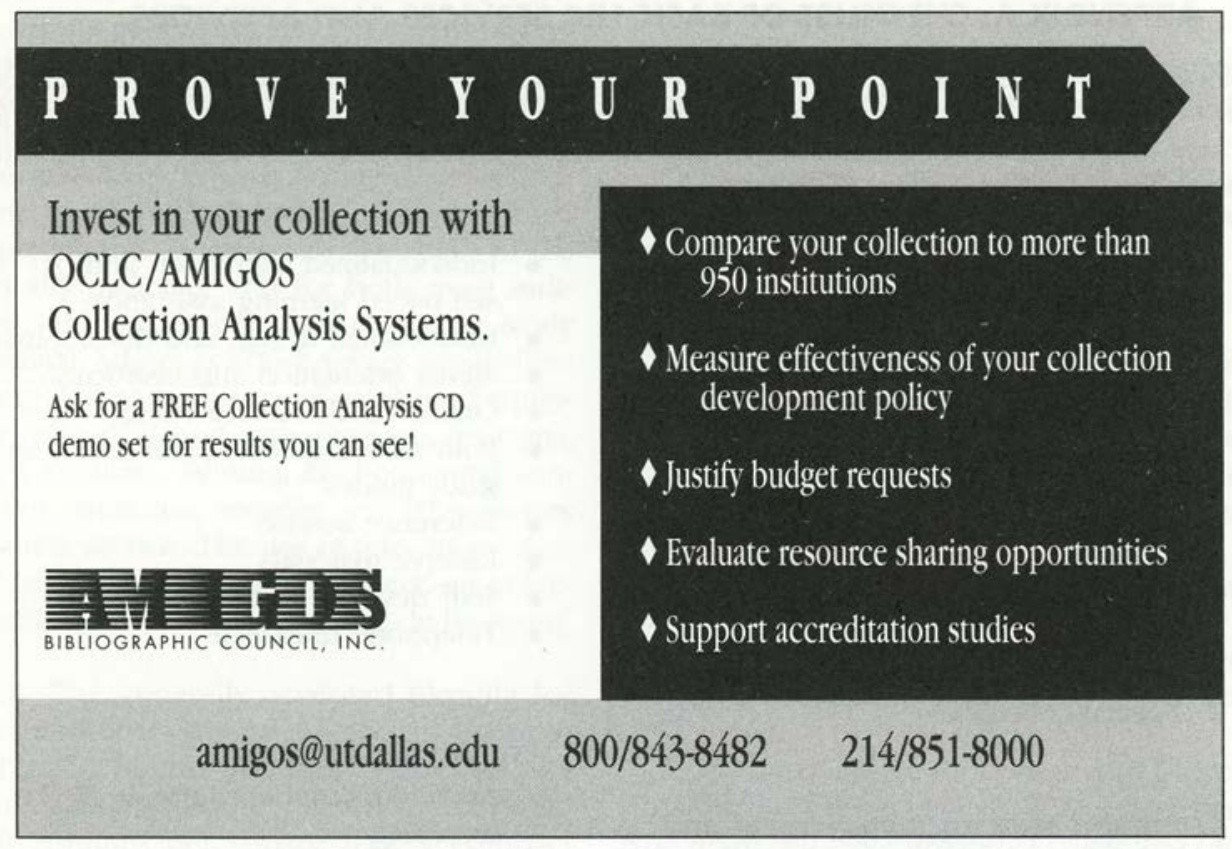

\section{APPENDIX B: CHECKLIST OF ADDITIONAL SERVICES COMPONENTS}

This list includes services which require capital funds, space, personnel, and operating budgets in excess of those included in Tables $\mathrm{A}, \mathrm{B}$, and $\mathrm{C}$.

\section{Community Services}

\section{Curriculum:}

- Library technician education

- Bibliographic instruction courses

\section{Faculty Development}

\section{Government Documents Depository} Joint-Use:

- Museum

- Other academic library

- Public library

- School library

Laboratories:

- Career

- Learning development

- Literacy

- Self-paced learning

- Testing

- Tutoring

\section{Literacy Programs}

Printing:

- College catalogs

- Copy services (not self-serve)

- Literary or other academic college publications

- Print shop

\section{Student ID Service}

Television/Radio:

- Radio broadcast

- Satellite uplink

- Telecourse administration

- Telecourse production

- Television broadcast

- Television station/Radio station administration 


\section{APPENDIX C}

Example: California Community Colleges Facilities Standards-Library Space (from Title 5, California Code of Regulations, Section 57030)

All library space shall be computed by assignable square feet for library functions as specified in the subdivisions of this section. Square feet are "assignable" only if they are usable for the function described. Areas such as the main lobby (excluding card catalogue area), elevators, stairs, walled corridors, restrooms, and areas accommodating building maintenance services are not deemed usable for any of the described functions.

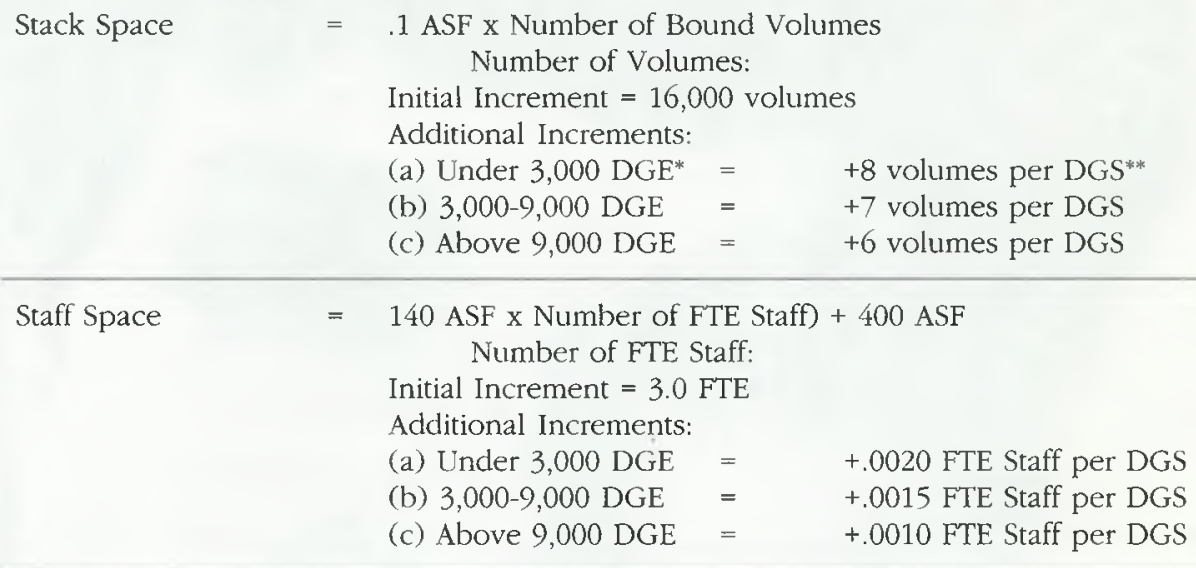

Reader Station Space $=27.5$ ASF x Number of Reader Stations

Number of Reader Stations:

Initial Increment $=50$ stations

Additional Increments:
(a) Under 3,000 DGE =
(b) 3,000-9,000 DGE =
+.10 Stations per DGS
(c) Above 9,000 DGE =
+.09 Stations per DGS
+.08 Stations per DGS

Total Space

$=\quad$ Initial Increment $=3,795 \mathrm{ASF}$

Additional Increments:
(a) Under 3,000 DGE =
(b) 3,000-9,000 DGE=
(c) Above 9,000 DGE =
+3.83 ASF per DGS
+3.39 ASF per DGS
+2.94 ASF per DGS

For audiovisual and programmed instruction activities associated with library functions, additional areas sized for individual needs but not exceeding the following totals for the district as a whole.

Total Space

$=$ Initial Increment
Additional Increments:
(a) Under 3,000 DGE $=$
(b) $3,000-9,000 \mathrm{DGE}=$
(c) Above 9,000 DGE $=$

$3,500 \mathrm{ASF}$

1.50 ASF per DGS

0.75 ASF per DGS

0.25 ASF per DGS

*Day-Graded Enrollment =

use FTES

${ }^{* *}$ Day-Graded Student = use FTES 


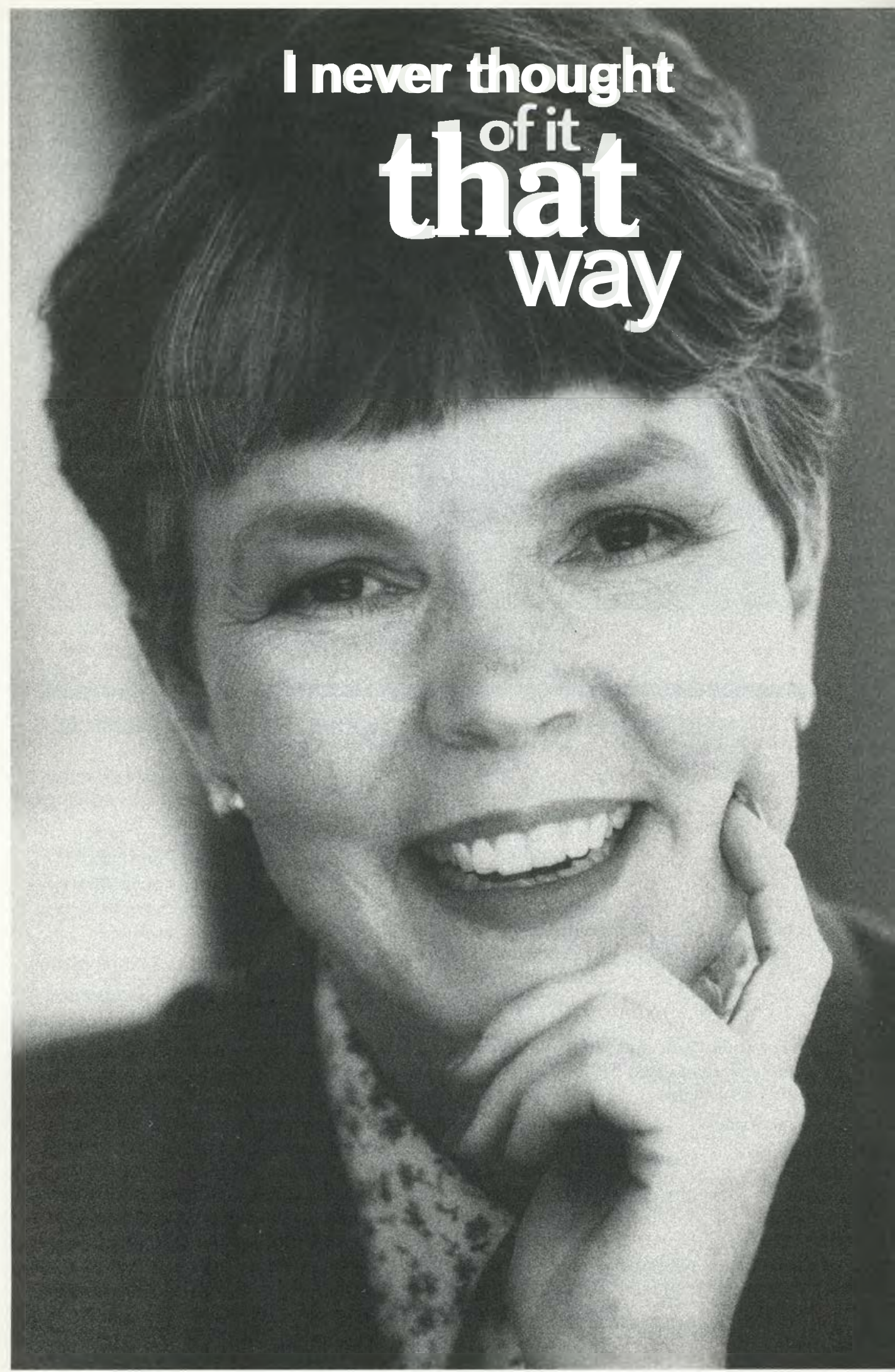




\section{Printed CA from CAS. 500,000 abstracts for about $3 ₫$ each. Good thinking.}

Every year, CAS carefully assembles one of the most comprehensive sources of scientific information you'll ever find. It's called the printed CA (Chemical Abstracts). And it's a research tool your library should own.

Think about it. CAS has over 800 scientists on staff to analyze the world's chemistry-related literature for you. They read more than 9,000 journals in 50 languages and produce over 500,000 abstracts. All for about $3 ₫$ per abstract.

500,000 abstracts. Where else can you get your hands on so much information?

With the printed CA, users can take their time when browsing through all the latest scientific information. There is no special training required to use $C A$, and familiarity with printed CA can help you use CA online more effectively. It's not surprising CA is found in leading libraries throughout the world and is used by thousands of scientists.

If you would like more information or if you're ready to order or renew the printed CA, call 1-800-933-4350 or 614-447-3731. We'll send you a handy companion booklet for CA plus some additional good reasons to renew or purchase a subscription.

There are some books you just have to own.

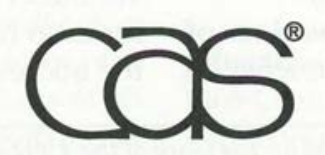

